\title{
ポリグラフ検査で出現する抑制性呼吸の発現機序
}

\author{
福井県警科学捜査研究所 \\ 黒原 彰 \\ 福井大学教育地域科学部 \\ 梅沢 章男
}

\section{Mechanisms underlying inhibitory breathing during the concealed information test}

\author{
Akira KUROHARA \\ Research Institute of Scientific Criminal Investigation, Fukui Prefectural Police H.Q, \\ 3-17-1 Ohte, Fukui 910-8515, Japan \\ Akio UMEZAWA \\ Faculty of Education and Regional Studies, Fukui University, \\ 3-9-1 Bunkyo, Fukui 910-8507, Japan
}

This article reviews evidence that the breathing pattern during the concealed information test (CIT) in the forensic research field consists of two different components. The first component is characterized by overall facilitation of ventilation: significant increments of inspiratory flow rate (respiratory drive) compared with the baseline resting level. The second component is characterized by a phasic inhibition of breathing following critical questions during the CIT paradigm: a decrement of respiratory flow rate and phasic prolongation of the post-exhalation pause time. From findings obtained in our previous studies on ventilation and gas exchange during stress and emotion, we suggest that the former tonic facilitation of breathing is similar with the breathing patterns observed during psychological stress, which reflects activation of the inspiratory drive in the respiratory center. Based on previous findings concerning the breathing patterns of subjects under attention, we also suggest that the phasic inhibition of breathing following critical questions could be caused by focusing attention on the CIT question, which reflects switching of control from respiratory center to the upper center. (Japanese Journal of Physiological Psychology and Psychophysiology, 27(1) : 35-44, 2009.)

Key words : respiration, inhibitory breathing, attention, emotion, concealed information test

2009.5.15 受稿, 2009.8.1 受理

1) 本研究の一部は平成 18 年〜 20 年度日本学術振興会科学研究費基盤研究（B）（課題番号 18300202，研究代表者梅沢章男）の補助を受けた。 
【要 約】本論文では, 法科学領域のポリグラフ検査, とりわけ裁決と非裁決質問に対する反応の違いをみるポ リグラフ検查 (concealed information test: CIT)において出現する呼吸活動が, ふたつの主要な成分から構成される ことを, これまでの実験結果に基づき考察した。第 1 の成分は, CIT 検査事態を通して誘発される吸気流速（呼 吸ドライブ機構）の変化であり, 安静時に比べて有意な増加を示す。第 2 の成分は, CIT 事態で呈示される裁決 質問に対する一過性の抑制性呼吸であり, 呼吸流速の低下や呼気後ポーズ時間の延長という特徵を持つ。本稿で は, ストレスや情動に伴う呼吸代謝活動に関する我々の実駼結果をもとに, 第 1 の変化成分は, ストレス, 情動 に伴う促進性呼吸と同じ性質を持つ呼吸変化であり，呼吸中枢の状態を反映したものと考察した。一方，後者の 成分である一過性の呼吸抑制は, 注意に伴う呼吸変化に関する先行研究の結果から, 裁決質問に対する注意レベ ルの上昇に起因した，呼吸中枢から上位中枢へと制御が切り替わって出現する変化であろうとの見解を示した。

\section{はじめに}

法科学領域におけるポリグラフ検査は, 応用生理心 理学の研究課題として, これまで多くの実務研究と基 礎研究が行われてきた (Kleiner, 2002)。わが国のポリ グラフ検査においては，裁決質問と非裁決質問の未梢 自律神経系反応パターンの違いを分析する手法 (concealed information test: CIT) が採用されている。これまで CIT をはじめとする検査手法を用いた実務研究が行わ れており, ポリグラフ指標のなかでも呼吸活動は, 鋭 敏な検出指標であることが報告されている（木崎・寒 河江・山岡, 1979 ; Timm, 1982)。これらの先行研究 では, 呼吸活動は胸郭あるいは腹部に巻いたピックア ップにより呼吸運動として測定されている（廣田・松 田・小林・高澤，2005）。呼吸曲線長（respiration line length: RLL）あるいは呼吸速度という独自の分析方法 が採用されている。

一方, ストレスや情動に関する呼吸の生理心理学研 究では, 呼吸活動の生理的な側面を反映する換気量や 呼気ガスパラメータを中心に知見が集積されてきた（梅 沢, 1998)。本稿は, ストレス, 情動の生理心理学的 知見を背景にして，独自の方法論で蓄積されてきた CIT の知見を読み解き, CIT で生じている呼吸変化が どのような呼吸系変容を背景にするものかを検討し， その背後にある発現機序について一定の見解を示すこ とを目標とする。

\section{実務 CIT 事態における呼吸運動変化}

ポリグラフ検查で用いられるCITにおいて, 事件 内容に関する認識を有していると判断する場合の呼吸 変化について, 経験的には波形の変化, とくに抑制性 の呼吸が判断基準として用いられてきた。実務のポリ グラフ検査の 1 例を Figure 1 に示した。裁決質問（critical question: CR）と非裁決質問（non-critical question: $\mathrm{nCR}$ ) から構成された 1 系列における皮膚伝導度反応（SCR）, 心拍数 (HR), 規準化脈波容積 (NPV), 呼吸運動 (RESP) のトレースを示したものである。視察レベルでも十分 に確認できるのは，CR に対する HR 低下と抑制性呼 吸の出現である。抑制性呼吸は呼吸数の顕著な低下と して現れている。

抑制性呼吸の中身について, CIT の呼吸パラメータ の值を引用しつつ, やや詳しく述べてみる。呼吸分析 パラメータには, 呼吸速度（上下方向への移動距離の 合計 /要した時間), 吸気速度 (上方向への移動距離 の合計 /要した時間), 呼気速度 (下方向への移動距 離の合計／要した時間), 振幅, 瞬時呼吸率 (各呼吸 の呼気開始時点の時間間隔から算出する 1 分あたりの 呼吸数) が用いられている。呼吸数以外はすべて任意 の単位 (arbitrary unit) である。

Figure 1 に示した CIT 記録に関する呼吸パラメータ の分析結果を見ると, nCR に対する瞬時呼吸率は7サ イクルから 10 サイクルの範囲であるが, CRに対して は 3 サイクルと, 呼吸数の著しい減少が認められる。

呼吸速度を分析したところ, nCR で 8 前後の值が $\mathrm{CR}$ では 4 と低下しており, 吸気速度では $\mathrm{nCR}$ が 10 から 14 の範囲であるのに対し， CR の值は 5 であった。 呼気速度も $\mathrm{CR}$ が 4 , nCR が 5 から 7 の值を示した。 このように速度パラメー夕は, いずれも CRにおいて 低い值を示していることが確認できた。

こうした CIT 記録は, 呼吸運動を指標として, CR と $\mathrm{nCR}$ の弁別が可能であることを示している。また 分析パラメータから得られた数量的な結果は, CIT の 先行研究における, 呼吸時間の延長などの抑制性変化 （木崎ら，1979），CRに対する呼吸曲線長（RLL）の 短縮（Timm, 1982）, あるいは呼吸速度の減少（足立, 


$$
\mu \mathrm{S}
$$

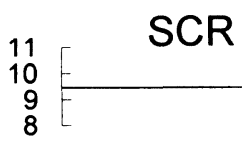

bpm

HR
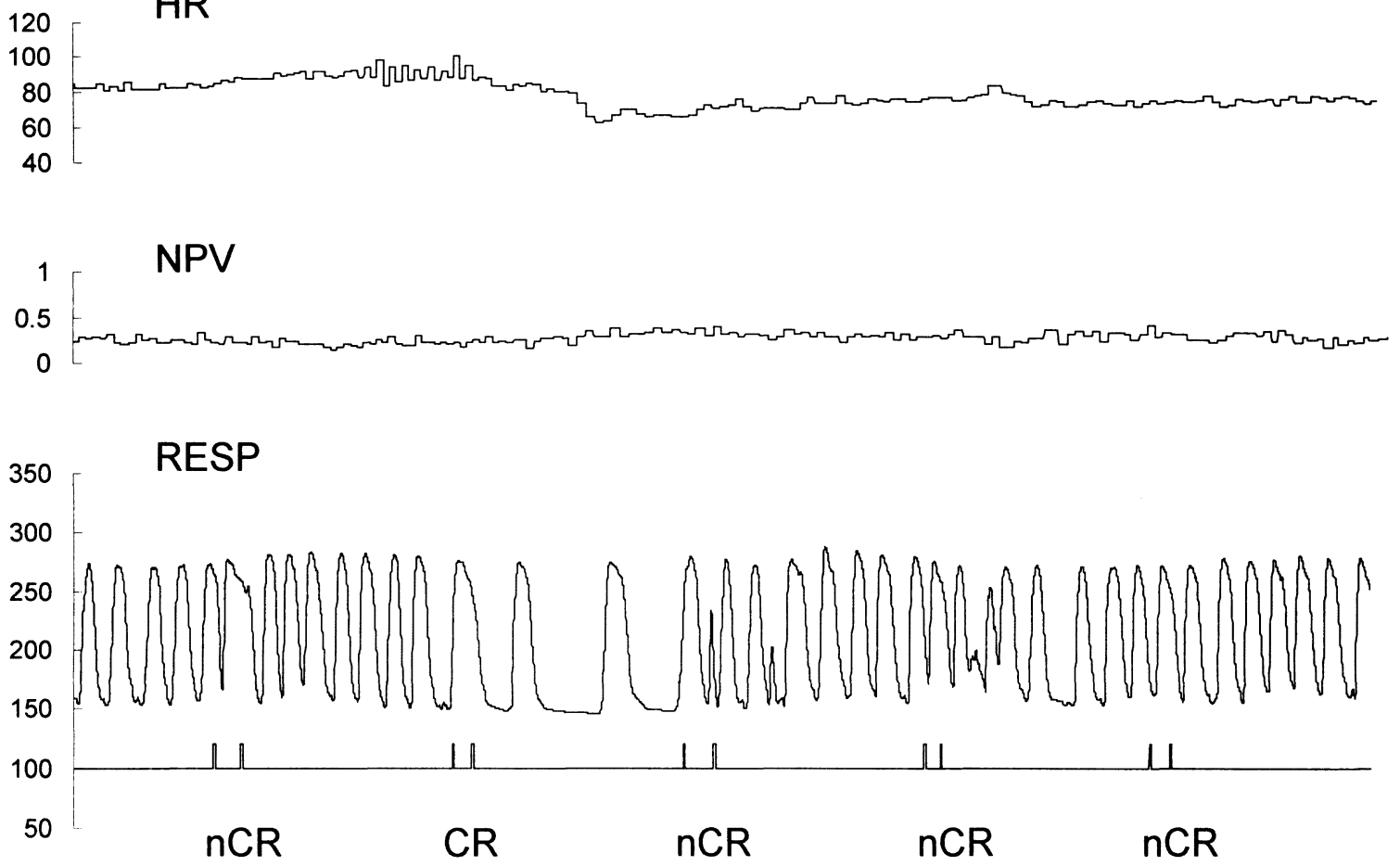

Figure 1. Typical polygraph recording of skin conductance response (SCR), heart rate (HR), normalized pulse volume (NPV), and respiration movement (RESP) following critical (CR) and non-critical (nCR) questions during the concealed information test (CIT) paradigm.

鈴木，1994）などの知見と基本的に一致したものと考 えられる。従って，このような分析パラメータの変化 が, どのような呼吸系変容を背景にしているかが問題 になる。

\section{模擬的 CIT 事態における呼吸系変容}

\section{$\mathrm{CIT}$ 事態とストレス事態の比較}

ストレス刺激は，呼吸系に促進的な変容をもたらす ことが確認されている（梅沢, 1991 ; Umezawa, 2001）。 また不快情動に伴い, 促進性の呼吸変化が生じること は多い（Boiten, Frijda, \& Wientjes, 1994)。ストレス刺 激や情動体験に伴い, 呼吸数（RR）と1 回換気量（TV） は多様な変化を示す。ある場合には RR は低下するし, 別の刺激では増加する。TVも増加する場合もあれば, 減少するときもある。しかし，刺激の種類を問わず
$\mathrm{RR} \times \mathrm{TV}$ で表される分時換気量は増加する。MillicEmili \& Grunstein（1976）は, 動脈血 $\mathrm{CO}_{2}$ レベルの上 昇に対する呼吸中枢の応答モデルを提案している。こ のモデルでは, 呼吸中枢に呼吸ニューロンの発火強度 を制御するドライブ機構と, 吸気と呼気の切り替えを 制御するタイミング機構を仮定する。ドライブは末梢 の吸気流速（吸気量／吸気時間）に反映され, タイミ ングは吸気と呼気の比率 (吸気時間/呼吸時間) に反 映される。動脈血中の $\mathrm{CO}_{2}$ 分圧上昇に対して, ドラ イブすなわち呼吸流速は増加を示すが, タイミングは 一定の値に維持される。

黒原・寺井・竹内・梅沢（2001a）は, ストレス事 態と CIT 事態が呼吸系に与える影響を比較している。 実験参加者は, 呼吸系に安定した変容をもたらす暗算, ビデオゲームのストレス事態と模擬的な CIT 事態を 
ともに経験した。Figure 2 はストレス事態と質問系列 を呈示しているCIT 事態全体のドライブを比較した ものである。CITにおけるドライブは, 暗算（MA） やビデオゲーム (VG) よりも小さいものの, 安静 (PR) を有意に上回る值を示した。ドライブ (吸気流速) は, 暗算やビデオゲームというストレス刺激に対して有意 な増加を示す。CIT 事態では, ストレス事態ほど顕著 ではないが, 安静と比較するとドライブは有意に高い 值を示した。このことから, 質問系列の呈示期間全体 を通してみると，少なくとも抑制性呼吸の兆候は認め られないことが明らかにされた。以上を要約すると, ストレスに伴う呼吸系変容は, 促進性の変容, すなわ ち動脈血二酸化炭素分圧 $\left(\mathrm{PaCO}_{2}\right)$ を下降させる変容 を基調とし，ストレス刺激に対して分時換気量とドラ イブは増大する。つまり, ストレス, 情動にともなう tonic な変化は促進性のものであり, ポリグラフ検査 事態でも安静時と比べれば tonic な促進性変化が生じ ている。このことから CIT 事態そのものは, ストレ 又刺激と同様に促進性変容をもたらすと考えられる。

\section{裁決質問に対する一過性変化}

我々は, $\mathrm{CR}$ と $\mathrm{nCR}$ の違いが換気と呼気ガスパラ メータにどのように反映されるかをまず検討した（黒 原ら，2001a）。それに加えて, 実務の CIT 事態で得ら れた呼吸速度の減少, 呼吸曲線長 (RLL) の短縮とい う呼吸運動マーカーが, どのような換気変化を反映し ているかを明らかにしようとした（黒原・寺井・竹内・

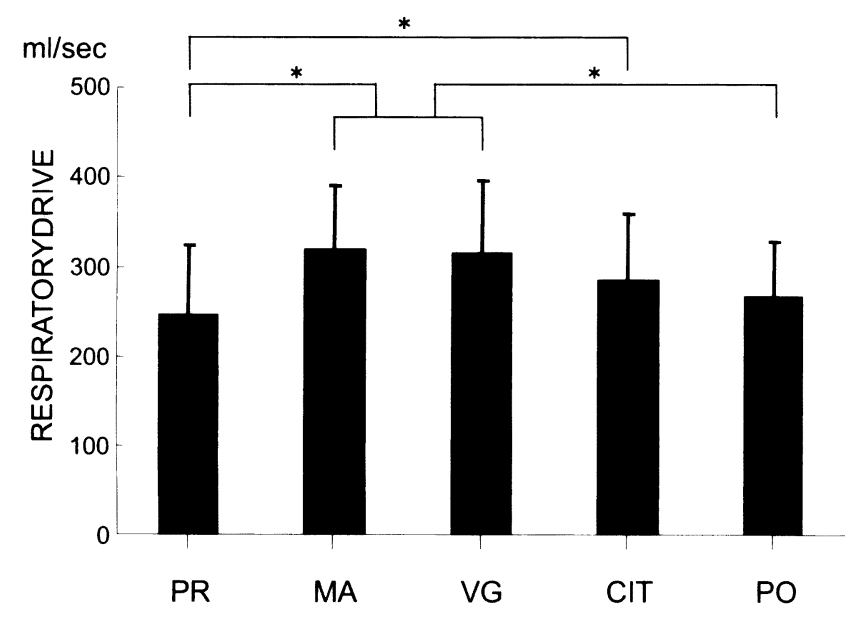

Figure 2. Mean and standard deviation of respiratory drive parameter during pre-trial rest (PR), mental arithmetic (MA), a video game (VG), the concealed information test (CIT), and post-trial rest (PO).
梅沢, 2001b)。模擬的な CIT 事態における換気変化 と呼気ガスを分析した結果, 換気と呼気ガスのパラメ ータでは，呼吸流速（respiratory flow rate）がもつと も鋭敏に CR と $\mathrm{nCR}$ の違いを弁別できることを見出し た。呼吸流速は, 単位時間当たりの換気量変化であり, $\mathrm{ml} / \mathrm{sec}$ が単位になる。Figure 3 は, CR と nCRについ て, 質問呈示前, 呈示, 返答各区間における平均流速 (mean flow rate: MFR), 吸気流速 (inspiratory flow rate: IFR) そして呼気流速 (expiratory flow rate: EFR) の平均值を示したものである。呼吸流速は, CR に対

$\mathrm{ml} / \mathrm{sec}$

(A)

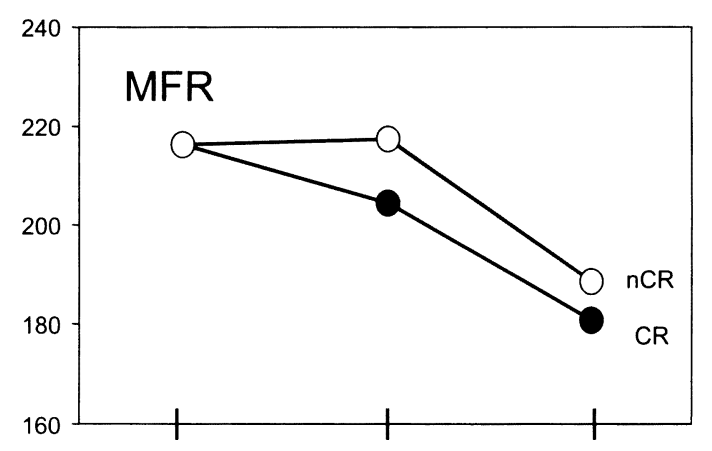

(B)

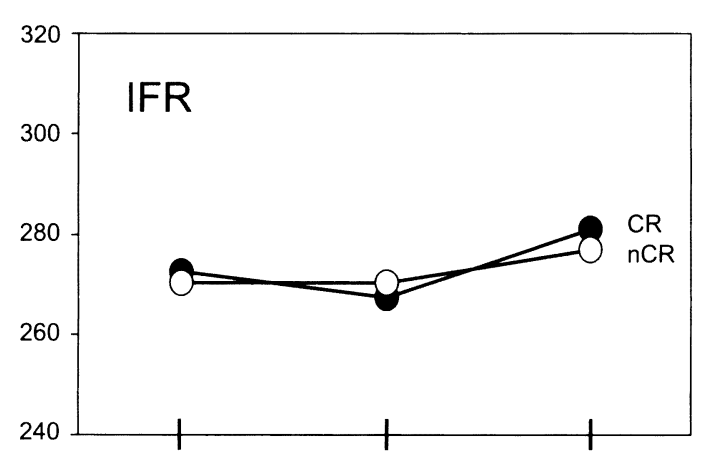

(C)

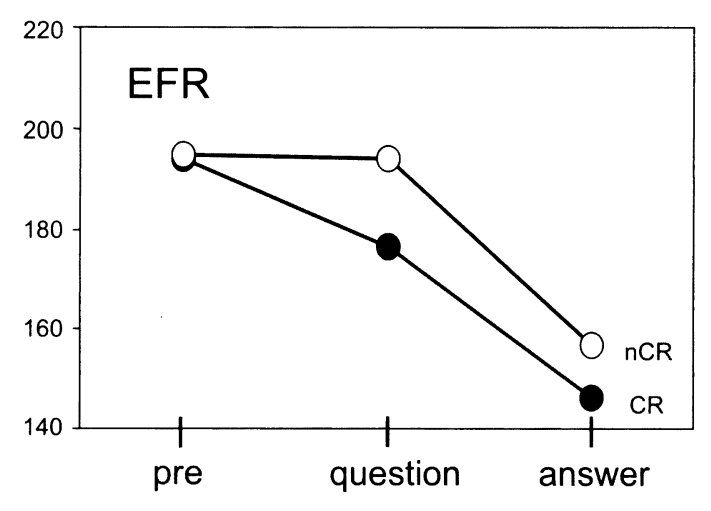

Figure 3. (A) Mean flow rate (MFR), (B) inspiratory flow rate (IFR), and (C) expiratory flow rate (EFR) in prequestion, question, and answer periods during the critical (CR) and non-critical (nCR) questions. 
して抑制性の変化を示すことが読み取れる。とくに EFRにその傾向が認められ，この実験では，抑制性 呼吸は EFR，つまり呼気流速の低下として現れた。 CIT による検査事態そのものは, 安静時と比較して, 呼吸流速を全般的に増加させる影響を及ぼす（tonic な影響)。しかし，CRに対しては一過性の抑制呼吸 が生じる (phasicな影響) ことを確認した。

CIT の先行研究では, 呼吸運動波形を分析するため に，呼吸曲線の長さをマニュアルで読み取るRLL（Timm, 1982）や，呼吸運動の加速度（velocity）を分析した 呼吸速度（respiration speed）（足立・鈴木，1994）と いう独自の測度が考案されてきた。呼吸数と振幅とい う伝統的な測度では，CR に対する抑制性呼吸を鋭敏 に検出できないことが，こうした独自の分析方法が開 発された理由と推察できる。黒原ら（2001b）は, RLL と呼吸速度がどのような換気変化を反映してい るかを調べている。その結果 RLL と呼吸速度は, 換 気の時間的測度 (例えば呼吸時間) や量的速度 (例え ば吸気量) との関連性は低いこと, むしろ平均流速 (MFR) や分時換気量という時間的, 量的変化をとも に反映する測度との対応関係があることを見出してい る。従って, 現行の CIT での分析測度である呼吸速度, 吸気速度そして呼気速度は，それぞれ平均流速，吸気 流速（ドライブ）そして呼気流速と対応していると考 えてよい。

黒原・梅沢（2004）は，模擬的な CIT 事態での呼 吸流速の抑制が, CR を呈示するだけで生じるのか, それとも CR に対する返答によって主に引き起こされ るのかを明らかにしようとした。CRあるいは nCRの 質問文をモ二タ画面に呈示してから $20 \mathrm{~s}$ 後に返答を 求めるメッセージを呈示し, 返答後 $20 \mathrm{~s}$ の呼吸代謝 活動を記録した。実験参加者 31 名から得られたデ一 夕を, 実務検査と同様に, 個人ごとに分析した結果, 流速の抑制は, 質問呈示, 返答時, 返答後のすべての 区間で認められた。質問を呈示するだけで呼吸流速の 抑制が生じることを示す結果である。流速の 3 測度の なかでは，呼気流速（EFR）の抑制を示す実験参加者 がもつとも多いが, 吸気流速（IFR）の抑制を示す者 も少なからず存在した。返答よりも質問呈示直後に EFR の抑制が多く示されることも明らかにされた。 つまり返答という呼吸系を動員する行為によって抑制 性呼吸がもたらされたわけではなく, CR そのものが
抑制性呼吸を誘発する刺激になっていることが確認で きた。従って, $\mathrm{CR}$ と $\mathrm{nCR}$ の差は, 呼吸流速にもっと も鋭敏に反映され，呼息相，次いで吸息相に生じる確 率が高いことから，呼吸サイクル全体，吸息相そして 呼気相と 3 つの区分で数量化することが望ましい。現 行のCITで, 呼吸速度, 吸気速度そして呼気速度が 主要な分析測度に採用されているのは, 妥当であると 考えられる。

以上の模擬的 CIT を用いた検討から, CIT 事態その ものは, ストレス刺激と同様に促進性の呼吸系変容を もたらすが， CRが呈示されると，流速抑制という一 過性の抑制性変容に置き換わることが確認された。

\section{呼吸系の生理的基礎}

\section{窒息回避システム}

ポリグラフ検査における抑制性呼吸は，どのような メカニズムで生じるのであろうか。この問題を検討す るためには，呼吸系のもつ特性をまず押さえておく必 要がある。呼吸系は, 周知のように生命活動を維持す るために必要な酸素 $\left(\mathrm{O}_{2}\right)$ を体内に取り込み, 代謝 の結果産出された炭酸ガス $\left(\mathrm{CO}_{2}\right)$ を体外に排出する ために日夜働いている。動脈血中の $\mathrm{O}_{2}$ 分圧と $\mathrm{CO}_{2}$ 分 圧が一定の值になるように，ホメオスタシス性の支配 を受ける系である。動脈血中 $\mathrm{O}_{2}$ 分圧は頝動脈小体に あるセンサーがチェックし，不足があれば換気の克進 が生じ, 呼吸数（RR）と1回換気量（TV）が増え, 分時換気量 $(\mathrm{VE}=\mathrm{RR} \times \mathrm{TV})$ が増加する。一方 $\mathrm{CO}_{2}$ 分 圧は動脈血の $\mathrm{pH}$ でモニタされ， $\mathrm{CO}_{2}$ 分圧上昇（ $\mathrm{pH}$ 低 下）が起これば，直ちにVEが増加する。 $\mathrm{O}_{2}$ と $\mathrm{CO}_{2}$ の どちらがより厳しくコントロールされているかという と， $\mathrm{O}_{2}$ 低下に対するよりも， $\mathrm{CO}_{2}$ 上昇に対する応答の 方がはるかに速く強力である (West, 2000)。つまり呼 吸系は $\mathrm{CO}_{2}$ の上昇を食い止めるために働くシステム であり，“窒息回避システム”と呼んで差し支えない。

\section{呼吸リズムの中枢制御}

延髄には，呼吸性リズムに同期して発射パターンを 変えるニューロン, すなわち呼吸性ニューロン群が存 在する（江連，1994）。呼吸性ニューロンは，その発 射パターンと呼吸周期との位相から，吸息相または呼 息相に発射するもの，あるいは両相にかけて発射する ものに分類され，放電頻度の時間的な推移から，漸増 型, 漸减型, プラト一型に区別されている（福原, 2000）。 
呼吸性ニューロンの主要なタイプは, 有田（1997）に よれば, (1) 漸増型吸気性ニューロン, (2) 漸減型吸気 性ニューロン, (3) 漸増型呼気性ニューロン, (4) 漸減 型呼気性ニューロンの 4 種類に大別される。漸減型吸 気ニューロンは, 吸気の最初に活動を高め, その後活 動を低下させていくニューロンである。吸気がスムー ズに行われるように, 吸気の最初に声門を開くという 機能を持つと考えられている。漸増型吸気性ニューロ ンは, 吸息相において徐々に発射頻度を上昇させる二 ユーロンであり，横隔膜などの吸気筋をコントロール する。肺と胸壁には弾性があるため吸気が進み, 肺が 膨張するにつれて元に戻ろうとする力は強まる。漸増 型吸気性ニューロンは肺, 胸壁の元に戻ろうとする力 に対抗するために徐々に発射頻度を上昇させる。

一方呼気性ニューロンについて, 漸減型呼気性二ュ 一ロンは, 呼息相の始めに発射頻度を上昇させるニュ 一ロンである。吸気によって膨らんだ肺と胸壁が, 呼 気に移ると弾性により一気に縮もうとするのにブレ一 キをかける役割をする。漸増型呼気性ニューロンは, 呼気の後半に発射頻度を上昇させるニューロンであり， 呼気筋の活動をコントロールする。

このように代謝要求 (metabolic demand) に沿った 自然呼吸のリズムは, 一生を通じて刻み続けられる。 この点では, 呼吸活動は, 生命活動に非常に密接に関 わる指標である。しかし一方, 呼吸は意識的に制御す ることもできるという体性系の機能を持ち, 泣く, 笑 うという情動行動の表出，あくび，咳，しゃっくりと いった行動, そして発声, 発語という高次な行動まで 関与する。こうしたさまざまな行為が, 自然呼吸とほ ぼ同じ筋群を用いて行われており，自律的な呼吸調整 と随意的な呼吸のコントロールが見事に切り替わり， 支障なく機能するというユニークさを持つ（有田，1997）。

\section{裁決質問に対する抑制性呼吸の発現メカニズム ストレス・情動に伴う抑制性呼吸}

ストレスに伴う呼吸系変化は, 分時換気量の増加（梅 沢, 1991), ドライブの増加（黒原, 2001a）そして呼 気終末炭酸ガス分圧 $\left(\mathrm{PetCO}_{2}\right)$ の低下 (寺井・梅沢, 2003）などの促進性変容を基調とする。これは闘争一 逃走反応の 1 側面を反映したもので, その後の激しい 運動に備えた変化と考えられている。情動, とりわけ 怒り, 不安などの不快な情動により, 呼吸系が促進性
変容を示すという知見は数多く提出されてきた（Boiten, et al., 1994). 快一不快の情動に伴う呼吸変化は, 基本 的には促進性変容であることも確認されている（梅沢・ 寺井, 2004 ; 梅沢・清水・寺井, 2004)。CIT 事態で 生じたドライブの増大（黒原ほか, 2001a）は, スト レス, 情動による変化と同様のものとみなすことがで きる。“窒息回避システム”としての呼吸系は, 外的 な変化に対応して促進性変容を示す。

それでは, ストレス, 情動に伴い抑制性の呼吸はま つたく出現しないのであろうか。限られた先行研究で はあるが，ストレス，情動に伴う抑制性呼吸について 報告されている（Anderson, 1998; Fokkema, Koolhaas, van der Meulen, \& Schoemaker, 1986; Fokkema, 1999; Dudley, Holmes, Martin, \& Ripley, 1963)。Dudley et al.（1961）は, 苛立ち, 怒り, 不安なぞ, それに伴っ て何らかの行為を発現させる (action oriented) 情動で は促進性変容が出現し, 抑鬱 (depression) やリラク セーションなど, 行為を伴わない (non-action oriented) 情動では呼吸の抑制が出現すると主張する。Anderson （1998）は, 動物実験ではあるが, 嫌悪条件づけで生 じる抑制性呼吸が, 高血圧発症の引き金になることを 示す一連の研究を報告している。Fokkema et al. (1986) と Fokkema（1999）は, 雄ラットが綿張り争いに敗れ た後, あるいは自分より優位な個体と, 体が接触せず 対峙した時に出現する持続性の緊張性呼吸（strained breathing) に注目している。この呼吸パターンを紹介 すると, 素早い吸気に引き続き, 呼気に移ろうとして も, 声門が開かないため呼出がブロックされた状態が 続き, 大気圧に比べて通常は陰圧を示す胸腔内圧が上 昇し, 陽圧に至る。ようゃく呼出ができたときには, 周囲に呼出音が響くほど, 激しい呼気が行われ, 反動 で素早い吸気が生じる。バルサルバ手技（市丸，1995） による呼吸が連続して行われることに等しいと述べて いる。以上の呼吸パターンを安静時と比較すると, 吸 気の素早さに表れるドライブの増加と, 声門閉鎖筋収 縮により呼気がブロックされた結果生じる呼気時間の 延長という二つの特徵を有する。Fokkema (1999)はこ の呼吸パターンが能動的行為の抑制, 予期, 注意など を反映するとし, 心臓疾患や突然死との関連性を指摘 している。

\section{情動仮説の検証}

ストレス刺激に対して呼吸は多様な変化を示すが, 
Obrist（1981）の枠組みでは受動的な対処課題に相当 する寒冷昇圧試験中に, Fokkema（1999）が示した緊 張性呼吸に近似した呼吸反応が出現する。その呼吸パ ターンは，吸気後ポーズがある息こらえ（breath holding） に似たものであり, ドライブ増加と吸気後ポーズによ る呼気時間の延長という, 緊張性呼吸と同じ特徵を持 つ。従って，裁決質問に対する呼吸パターンに同様の 特徵が認められるのであれば，裁決質問に対する抑制 性呼吸はストレス反応と捉えることができる。

Figure 4 上段には緊張性呼吸（strained breathing）, 下段には裁決質問に対する抑制性呼吸の典型例を模式 的に示したものである。呼吸パターン，胸腔内圧，呼 気動作に関与する腹直筋及び漸減型呼気二ューロンの 仮想的な発射パターンをそれぞれ示した。両者は呼吸
時間の長さという点では同じ特徵を持つが, 換気とい う点で大きな違いがある。緊張性呼吸では, 吸気後ポ 一ズが, 長い呼吸時間の原因であるのに対し, CIT 事 態での抑制性呼吸は, 呼気後ポーズの延長に特徵があ る。加えて, 前者では吸気後ポーズは呼出ブロックが 背景にあり, 胸腔内圧が上昇するのに対し, 後者の呼 気後ポーズでは, 胸腔内圧はやや陰圧で保持されてい ると推定できる。ドライブ (吸気流速) 及び呼気流速 についても, 前者では素早い吸気と呼出音が響くほど の激しい呼気という特徵から, 吸気と呼気の流速が増 加していることが推察できるのに対し, 後者における ドライブ (吸気流速) と呼気流速はともに抑制される。 呼息相の始めに発射頻度を上昇させる漸減型呼気性 ニューロンは, 既述したように, 咽頭の声門閉鎖筋を

(A)

volume

ntrathoracic pressure

rectus abdominis

expiratory neurons

(decrescendo type)

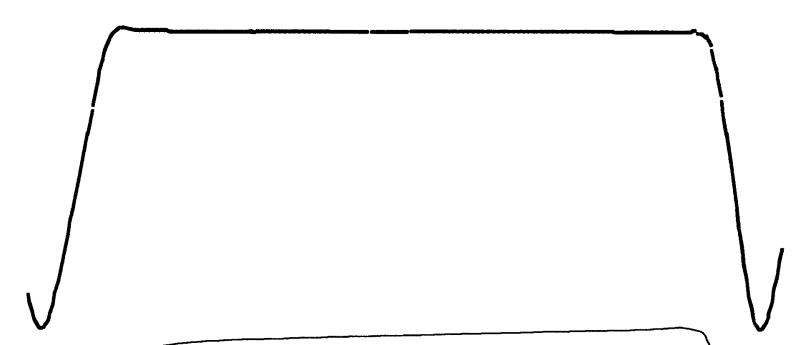

(B)

volume

Intrathoracic pressure

rectus abdominis

expiratory neurons (decrescendo type)

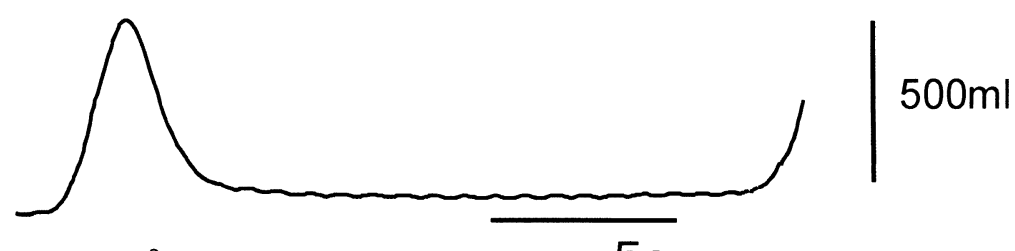

Figure 4. Characteristic differences between (A) strained breathing observed during a social stress condition (Fokkema, 1999) and (B) typical inhibitory breathing in response to a critical question during the concealed information test (CIT) paradigm. 
収縮させ，吸気によって膨らんだ肺と胸壁が弾性によ り一気に縮もうとするのにブレーキをかけ，気流をコ ントロールする役割がある（有田，1997）。緊張性呼 吸と CIT 事態の呼吸パターンを比較すれば, 声門閉 鎖筋は緊張性呼吸のポーズ時で持続的に放電している が，裁決質問に対する抑制性呼吸では呼息相の最初で のみ活動を高め, それ以降減衰していくことが容易に 予想できる。そもそも自然呼吸では吸気は積極的なプ ロセスであるのに対し，呼気は拡大した肺と胸壁がも とに戻る力を利用した受動的なプロセスである。ふた つの呼吸パターンには, このように呼気プロセスの積 極性に大きな違いがある。従って, ポリグラフ検査時 に見られる呼吸抑制は，ストレス・情動に伴う抑制性 呼吸とは，異なる生理的バックグラウンドを持つと考 えてよいだろう。

裁決質問に対して生じる抑制性呼吸, すなわち呼気 後のポーズが延長した呼吸パターンに近似したものは, 動脈血中炭酸ガス分圧 $\left(\mathrm{PCO}_{2}\right)$ が低くなり, 換気の 必要性が低下したときに出現する。例えば自発的な過 換気 (hyperventilation) を課した後に, こうした呼吸 パターンは出現する。しかし, 裁決質問に移る前に, 過換気のエピソードが観察されなくても, Figure 5 に 示すような $30 \mathrm{~s}$ にも及ぶ呼吸停止が認められる。こ のような変化が, 感情やストレスに伴う過換気に由来 したもの, あるいは呼吸系そのものの合目的的な反応
の結果とは考えにくい。実務の CIT 事態でも模擬的 なそれでも， CR 呈示によって生じる抑制性呼吸はス トレス, 情動性変化を反映したものではないと結論で きよう。窒息回避システムとしての呼吸系が, $30 \mathrm{~s} に$ も及ぶ呼吸停止を発現させるとは考えにくい。むしろ, 抑制性呼吸の発現プロセスには，上位中枢の関与を考 えるのが妥当であろう。

\section{「注意一感情」仮説による抑制性呼吸の吟味}

それでは，どのような中枢性の関与が考えられるの であろうか。もつとも有力なものがく注意一感情>モ デルである（Denot-Ledunois, Vardonb, Perruchet, \& Gallego, 1998; Sawada, Nagano, \& Tanaka, 2002 ; 澤田, 2006）。澤田（2006）は, CIT 事態が受動的対処事態 （Orbist，1981）であり，＜注意一感情＞モデルに照ら せば，感情よりもいっそう注意が高まる，いわば「注 意／感情>1」の状態であるとしている。能動的対処 事態, あるいは「注意 /感情 $<1 」$ の状態では, 心臓 優位反応パターンが誘発されるが, 受動的対処事態や 「注意／感情> $1 」$ の状態では, 血管優位反応パター ンに移行すると述べている。CIT 事態の裁決質問に対 しては血管収縮が誘発されると予測し, 廣田・高澤 （2002）あるいは廣田・澤田・田中・長野・松田・高 澤（2003）の知見はそれを裹付けると述べている。澤

田（2006）は，CIT 事態の裁決質問に対する呼吸抑制 にも言及しており，ストレス刺激の負荷事態で血管有

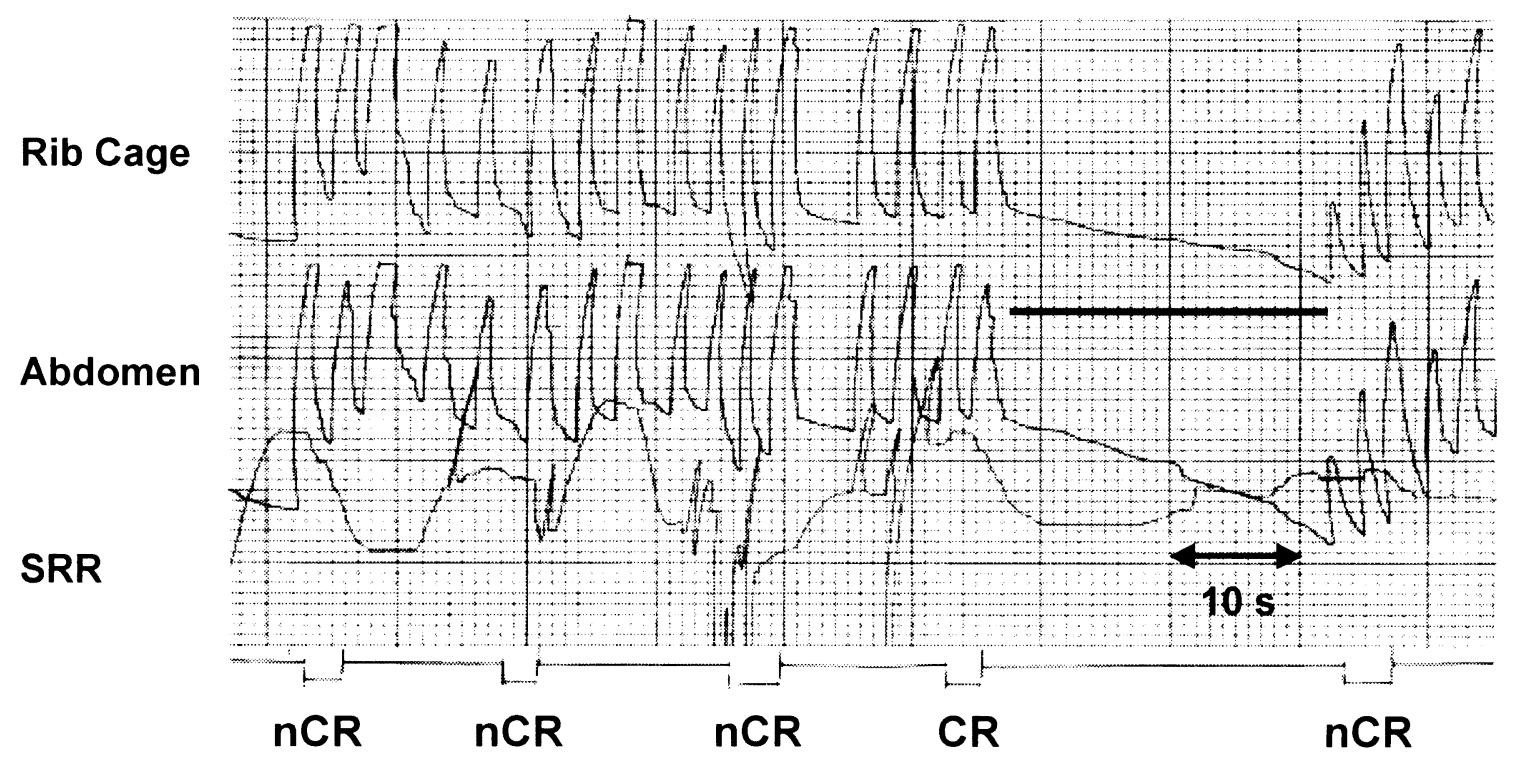

Figure 5. Typical inhibitory breathing with a long post-exhalation pause time during a critical item (CR) compared with non-critical items (nCR) in the field setting. 
意反応パターンと呼息期の呼吸抑制および停止が併存 することがほとんどないことから，呼吸抑制と血管優 位反応パターンは, 別建てのプロセスが重畳したもの と論考している。

Denot-Ledunois et al. (1998) は, ビデオゲームの難易 度を段階的に上昇させ, 画面に向ける注意の量を高め たとき, 呼吸時間が有意に延長することを見出してい る。つまり, 同じテレビゲーム課題でも, 易課題では 情動変化が前面に出て, 呼吸は早くなるが, 画面に注 意を払う必要が高まる難課題では, 呼吸の抑制が生じ ると述べている。Takasawa, Matsuda, \& Hirota (2004) では, ひとつのスピーカから周波数が段階的に高くな る音刺激を出し, もうひとつのスピーカから段階的に 周波数が低くなる刺激を同時に呈示するという聴覚課 題（tone accordance detection task）を考案し，その時 の呼吸抑制を調べている。聴覚と視覚の Go/No-Go 課 題も合わせて実施しているが, どちらも注意の配分を 実験的に操作する課題である。ふたつの音の周波数が 接近し, 臨界点 (critical point) に近づくプロセス, あるいは Go/No-Go が要請される時点に近づくときの, 呼吸運動の加速度パラメータを分析している。その結 果, 注意の配分が増加するであろうプロセスで, 吸気 と呼気の加速度は低下することを確認し, 注意の増加 が呼吸の抑制をもたらしたと結論づけている。

Fokkema, Maarsingh, van Eykern, \& van Aalderen (2006) は，喘息患児と健常児の安静と暗算事態におけ る呼吸と呼吸筋活動を比較している。その結果, 喘息 患児は健常児と比べて, 安静, 暗算両事態を通してゆ っくりと呼吸すること, 吸息期で胸壁が最大に広がる 時点と横隔膜笳電図の放電パターンに違いがあると述 ベている。すなわち, 健常児は胸壁の広がりと筋放電 のピークが一致しているのに対して, 喘息患児の筋放 電は先行して出現するという。安静な状態でも, 横隔 膜筋電図は最大放電にすばやく到達する。このことは, 喘息患児が吸気動作を周到に準備していることを示す データであり，喘息患児は日頃から呼吸困難感 (breathlessness) に襲われることに不安を抱いており, 気道閉塞を防止するために, 呼吸流速を抑えた “注意 深い”呼吸パターン（careful breathing pattern）を身に つけていると解釈している。

以上の知見は CIT 事態で得られたものではないが, 検査事態が被測定者の注意を喚起する場合, 呼吸系に
抑制反応が生じると考えてよい根拠になるデータと考 えられる。少なくとも吸気や呼気流速の抑制，あるい は呼吸時間の延長は, 被測定者の裁決質問に対する注 意配分が，なんらかの理由で増加した結果と解釈でき る。また Fokkema et al. (2006)にあるように，注意は 外の刺激に対するものとともに，身体を含めた内部へ の注意配分の上昇に由来する可能性もあろう。

以上述べてきた CIT 事態の呼吸変化をまとめると, 検査事態そのものは呼吸系に促進性変容をもたらす。 それはストレス, 情動反応と同様に, 呼吸中枢の変化 がそのまま反映したものと考えられる。ところが, 裁 決質問が呈示されると，より上位の中枢に制御が移り， 内的，外的環境に向かう注意レベル上昇を反映した抑 制性呼吸に切り替わる, というのが本論の結論である。 また, CIT 事態の呼吸抑制を「注意」と捉えることで, CIT 事態における呼吸・心臟血管系変容を, <注意一 感情>モデルで統一的に説明することが可能と考えて いる。今後に残された課題として, 模擬的な CIT 事 態において，注意配分がある䦭値を越えたとき，呼息 期に長時間の呼吸停止が実務検査と同様に生じるのか ということを確認する必要がある。

\section{引用文献}

足立浩平・鈴木昭弘 (1994). 集団デー夕の統計解析 に基づくポリグラフ検査の自動判定法. 科学警察研 究所報告, 47, 9-16.

Anderson, D. E. (1998). Cardiorenal effects of behavioral inhibition of breathing. Biological Psychology, 49, 151163.

有田秀穂 (1997)。呼吸の神経性調節。Clinical Neuroscience, 15, 1192-1193.

Boiten, F. A., Frijda, N. H., \& Wientjes, C. J. E. (1994). Emotions and respiratory patterns: Review and critical analysis. International Journal of Psychophysiology, 17, 103-128.

Denot-Ledunois, S., Vardonb, G., Perruchet, P., \& Gallego, J. (1998). The effect of attentional load on the breathing pattern in children. International Journal of Psychophysiology, 29, 13-21.

Dudley, D. L., Holmes, T. H., Martin, C. J., \& Ripley, H. S. (1963). Changes in respiration associated with hypnotically induced emotion, pain, and exercise. 
Psychosomatic Medicine, 26, 46-57.

江連和久 (1994)。延髄呼吸性二ューロン群の分類 神経研究の進歩, 38, 353-364.

Fokkema, D. S., Koolhaas, J. M., van der Meulen, J., \& Schoemaker, R. (1986). Social stress induced pressure breathing and consequent blood pressure oscillation. Life Sciences, 38, 569-575.

Fokkema, D. S. (1999). The psychobiology of strained breathing and its cardiovascular implications: A functional system review. Psychophysiology, 36, 164-175.

Fokkema, D.S., Maarsingh, E.J.W., van Eykern, L.A.. van Aalderen, W.M.C. (2006). Different breathing patterns in healthy and asthmatic children: Responses to an arithmetic task. Respiratory Medicine, 100, 148-156.

福原武彦 (2000). 呼吸中枢神経機構の機能構成と呼 吸リズム形成神経機構. 本田良行・福原武彦（編） 新生理学体系 17 呼吸の生理学 医学書院 pp. 98-127.

廣田昭久・高澤則美（2002）。精神生理学的虚偽検出 における末梢皮膚血流量. 生理心理学と精神生理学, 20, 49-59.

廣田昭久・澤田幸展・田中豪一・長野祐一郎・松田い ずみ・高澤則美（2003）。新たな精神生理学的虚偽 検出の指標：規準化脈波容積の適用可能性. 生理心 理学と精神生理学, 21, 217-230.

廣田昭久・松田いづみ・小林一彦・高澤則美（2005）。 携帯型デジタルポリグラフ装置の開発, 日本法科学 技術学会誌，10，37-44.

市丸雄平（1995）。バルサルバ試験 日本自律神経学 会（編）自律神経機能検査第 2 版, pp. 16-22.

木崎久和・寒河江正男・山岡一信（1979）。ポリグラ フ検査における呼吸パターンの分類化と得点化の試 み. 科学警察研究所報告, 32, 136-141.

Kleiner, M. (Ed.) (2002). Handbook of Polygraph Testing, San Diego: Academic Press.

黒原 彰・寺井堅祐・竹内裕美 - 梅沢章男 (2001a). 呼吸運動の虚偽検出マーカーが反映する呼吸系変容. 日本鑑識科学技術学会誌, 6, 27-34.

黒原 彰 - 寺井堅祐 - 竹内裕美 - 梅沢章男 (2001b). 虚偽検出における呼吸系変容 一裁決質問に対する 抑制性呼吸の発現機序一。生理心理学と精神生理学, 19, 75-86.
黒原 彰・梅沢章男 (2004). 虚偽検出事態における 抑制性呼吸に関する研究. 生理心理学と精神生理学,

22, 117.

Milic-Emili J. and Grunstein M.M.(1976). Drive and timing components of ventiration. Chest, 70 (Suppl), 131-133.

Obrist, P. A. (1981). Cardiovascular psychophysiology: a perspective. New York: Plenum Press.

Sawada, Y., Nagano, Y., \& Tanaka, G. (2002). Mirror tracing and the provocation of vascular-dominant reaction pattern through heightened attention. Journal of Psychophysiology, 16, 201-210.

澤田幸展（2006）。血圧反応性再訪 生理心理学と精 神生理学, 24, 257-271.

Takasawa, N., Matsuda, I., \& Hirota, A. (2004). Attention focusing suppresses the respiratory movement International Journal of Psychophysiology, 54, 184-185. (Abstract)

寺井堅祐・梅沢章男 (2003). 呼吸セルフコントロー ルのリラクセーションに及ぼす効果一呼気終末炭酸 ガス分圧のバイオフィードバックによる検討. バイ オフィードバック研究，30，31-37.

Timm, H. W. Analyzing deception from respiration patterns(1982). Journal of Police Science and Administration, 10, 47-51.

梅沢章男（1991）。ストレス刺激に対する呼吸活動の 変容. 生理心理学と精神生理学, 9, 43-55.

梅沢章男（1998）。呼吸活動 宮田 洋（監修）藤澤 清・柿木昇治・山崎勝男（編） 新生理心理学 1 巻 生理心理学の基礎 北大路書房 pp.196-209.

Umezawa, A. (2001). Facilitation and Inhibition of Breathing During Changes in Emotion. In Y. Haruki, I. Homma, A. Umezawa, \& Y. Masaoka (Eds.), Respiration and Emotion. Springer-Verlag: Tokyo, pp. 139-148.

梅沢章男・寺井堅祐（2001）。呼吸活動によるリラク セーション評価のパラダイム. 生理心理学と精神生 理学, 19, 69-74.

梅沢章男・清水亮子・寺井堅祐（2004）。情動に伴う 呼吸・心臓血管系変容. 生理心理学と精神生理学, 22 , 117.

West, J. B. (2000). Respiratory Physiology: The Essentials 6th ed. Lippincott Williams \& Wilkins. 